\title{
The chironomid fauna of the Ourthe basin, Belgium : additions to the Belgian check-list of Chironomidae (Diptera)
}

\author{
M. Evrard ${ }^{1}$
}

Keywords : Diptera, Chironomidae, Belgium, checklist, river, Ourthe.

Four samples of pupal exuviae of Chironomidae (Diptera) were collected from 8 sites of the Ourthe basin from April 1994 to August 1994. These collections were used to determine normal seasonal trends. The samples yielded a total of one hundred and seven species. Seveteen are new to the fauna of Belgium with a possible additional three taxa (*). A taxonomic list of the species with locations, ecological features and periods of sampling is given, in a table which allows comparison with previous checklists.

Mots clés : Diptera, Chironomidés, Belgique, liste taxonomique, rivière, Ourthe.

Les Chironomidés (Diptera) du bassin de l'Ourthe, Belgique : additifs à l'inventaire des Chironomidés belges

Quatres récoltes d'exuvies nymphales de Chironomidés (Diptera), effectuées en avril 1994 et en août 1994 dans le bassin de l'Ourthe, ont permis de dénombrer 107 espèces de Chironomidés. Il s'agit, pour 17 espèces $(*)$, de premières citations pour la faune belge. Trois taxons supplémentaires sont également susceptibles d'être de nouvelles citations. L'inventaire taxonomique des espèces, la localisation et la caractérisation des sites de même que les périodes d'échantillonnage sont fournis sur un tableau qui permet la comparaison avec les listes précédemment établies.

\section{Introduction}

In recent papers the pupal life stage of the Chironomidae (Diptera) has drawn increasing attention (Ketttani et al. 1994 ; Ruse \& Wilson 1995). Since the publication of the list of Chironomidae in Belgium (Goddeeris \& Behen 1991) additional records have been given by Evrard (1994a,b). Research on pupal exuviae in the Walloon part of Belgium has yielded to the discovery of numerous new records belonging to the Belgian chironomid fauna. The present study was undertaken to understand the species composition of chironomids to be used as water quality indicators in the Ourthe basin, in sites which have different water quality.

1. Unité d'Ecologie des Eaux Douces (UNECED), Facultés Universitaires Notre-Dame de la Paix, rue de Bruxelles 61, B-5000 Namur, Belgium.
Previous work by Micha (1969) has shown that samples of benthic macroinvertebrates revealed organic pollution along the lower Ourthe. So far the studies in the Ourthe basin were only destined to the survey of benthic fauna as water quality indicators in the calculation of biotic indexes. These investigations have revealed a severe pollution of the river Vesdre. The river Amblève presents intermediate features. The upper Ourthe stays a undamaged stream with a great benthic diversity (Herman et al. 1985). Nowadays, the quality level of these rivers remains equivalent, a slight improvement is observed in the river Vesdre, due to the closing of old polluting factories, but the water quality level is still low. The upstream stations of the river Amblève present all the characteristic of a high water quality level, the river quality deteriorate downstream (Institut d'Hygiène et d'Epidémiologie, 1991). 


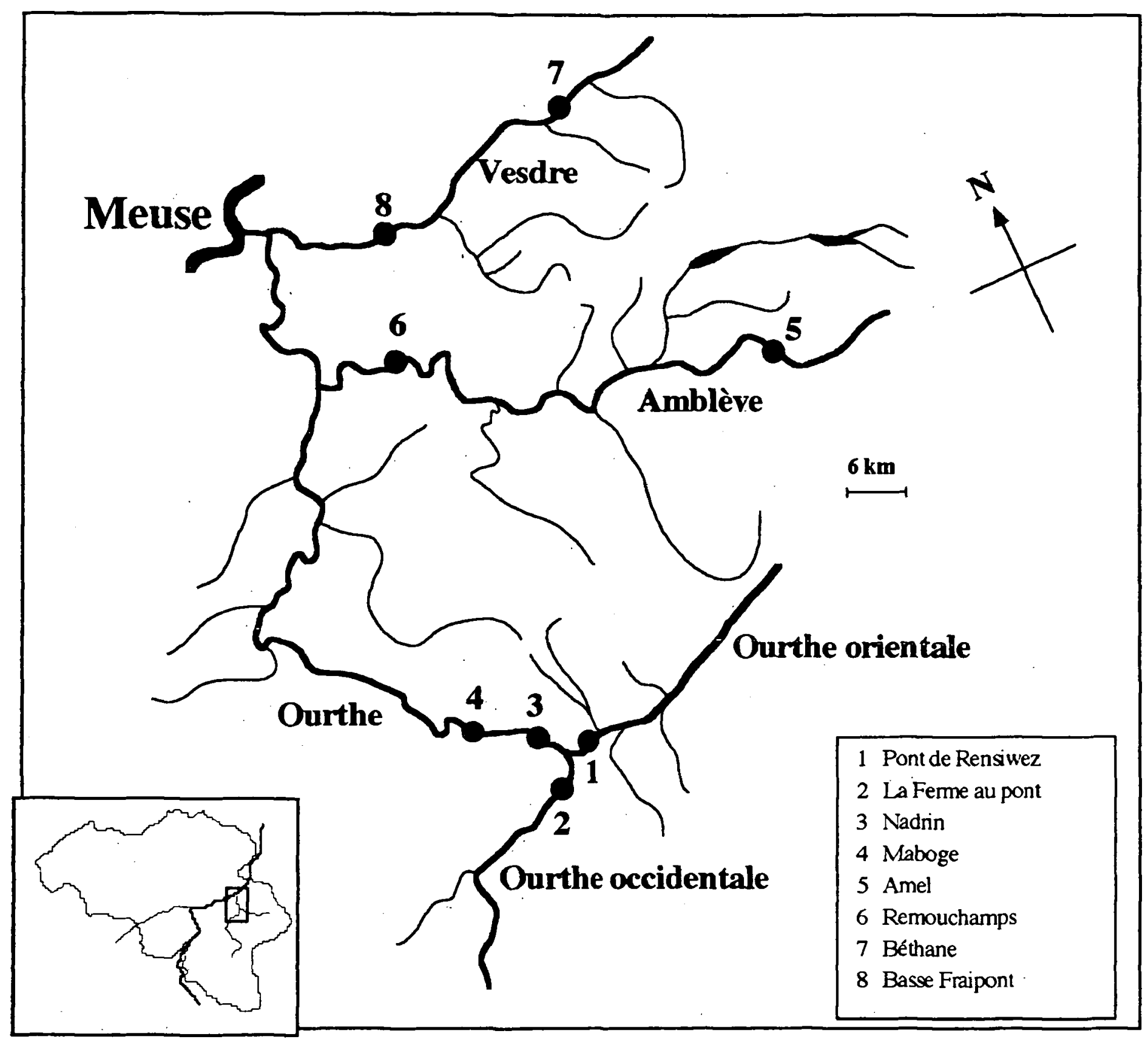

Fig. 1 : Map showing the sampling sites ( 1 to 8 ) in the Ourthe basin.

Fig. 1: Localisation des sites d'échantillonnage (1 à 8) dans le bassin de l'Ourthe.

\section{Material and methods}

The study was carried out in 5 streams of the Ourthe basin (East Belgium) (Fig. 1). In April, May, June and August 1994, samples were obtained from one site in the Ourthe Orientale, one in the Ourthe Occidentale, two in the Ourthe, two in the Vesdre and two in the Am- blève. All the sites were visited during the same day. The substrate in most of the sites is composed mainly of blocks and stones. In summer due to the fall of the water level, large beaches of rocky substrates appear. Some ecological features on the collection sites are given in Table 1. Means air temperature and means rainfall recorded between 1980 and 1993 (Fig 2.) show a typi- 
Table 1 : Ecological features of the 8 sites sampled in the Ourthe basin (Fig. 1) during the spring and the summer 1994. $\left(^{*}\right)$ from the confluence between the Ourthe Occidentale and the Ourthe Orientale.

Tableau 1 : Caractéristiques écologiques des 8 stations du bassin de l'Ourthe (Fig. 1) durant le printemps et l'été 1994. (*)à partir de la confluence de l'Ourthe Occidentale et de l'Ourthe Orientale.

\begin{tabular}{|c|c|c|c|c|c|c|c|c|}
\hline Stations & $\begin{array}{c}\text { Oriental } \\
1\end{array}$ & $\begin{array}{c}\text { Occidental } \\
2\end{array}$ & $\begin{array}{l}\text { Ourth } \\
=3\end{array}$ & 4 & $\begin{array}{c}\text { Ambl } \\
5\end{array}$ & eve & $\begin{array}{c}\text { Vesd } \\
7\end{array}$ & e \\
\hline Distance from the source $(\mathrm{km})$ & 34 & 43 & $0(*)$ & $14\left(^{*}\right)$ & 15 & 70 & 26 & 58 \\
\hline Altitude (m) & 310 & 295 & 280 & 240 & 405 & 137 & 237 & 100 \\
\hline Mean depth (m) & 0,5 to 1 & 0,1 to 0,5 & 0,5 to 1 & 0,5 to 1 & 0,1 to 0,5 & 0,1 to 0,5 & 0,1 to 0,5 & 0,5 to 1 \\
\hline Mean width (m) & 15 & 20 & 26 & 24 & 10 & 25 & 15 & 20 \\
\hline Slope (\%) & 4,01 & 3,96 & 2,786 & 1,449 & 2,893 & 2,267 & 3,246 & 1,494 \\
\hline Water Temperature $\left({ }^{\circ} \mathrm{c}\right)$ (April 94-August 94 ) & $8,5-16,4$ & $9-18,1$ & $10,2-15,5$ & $9,4-16,7$ & $8,3-16,1$ & $9,5-19,9$ & $6,4-13,8$ & $9,5-15,6$ \\
\hline Global Biologic Index (/20) (I.H.E. 1991) & 17 to 20 & 17 to 20 & 13 to 16 & 17 to 20 & 17 to 20 & 9 to 12 & 5 to 8 & 1 to 4 \\
\hline
\end{tabular}

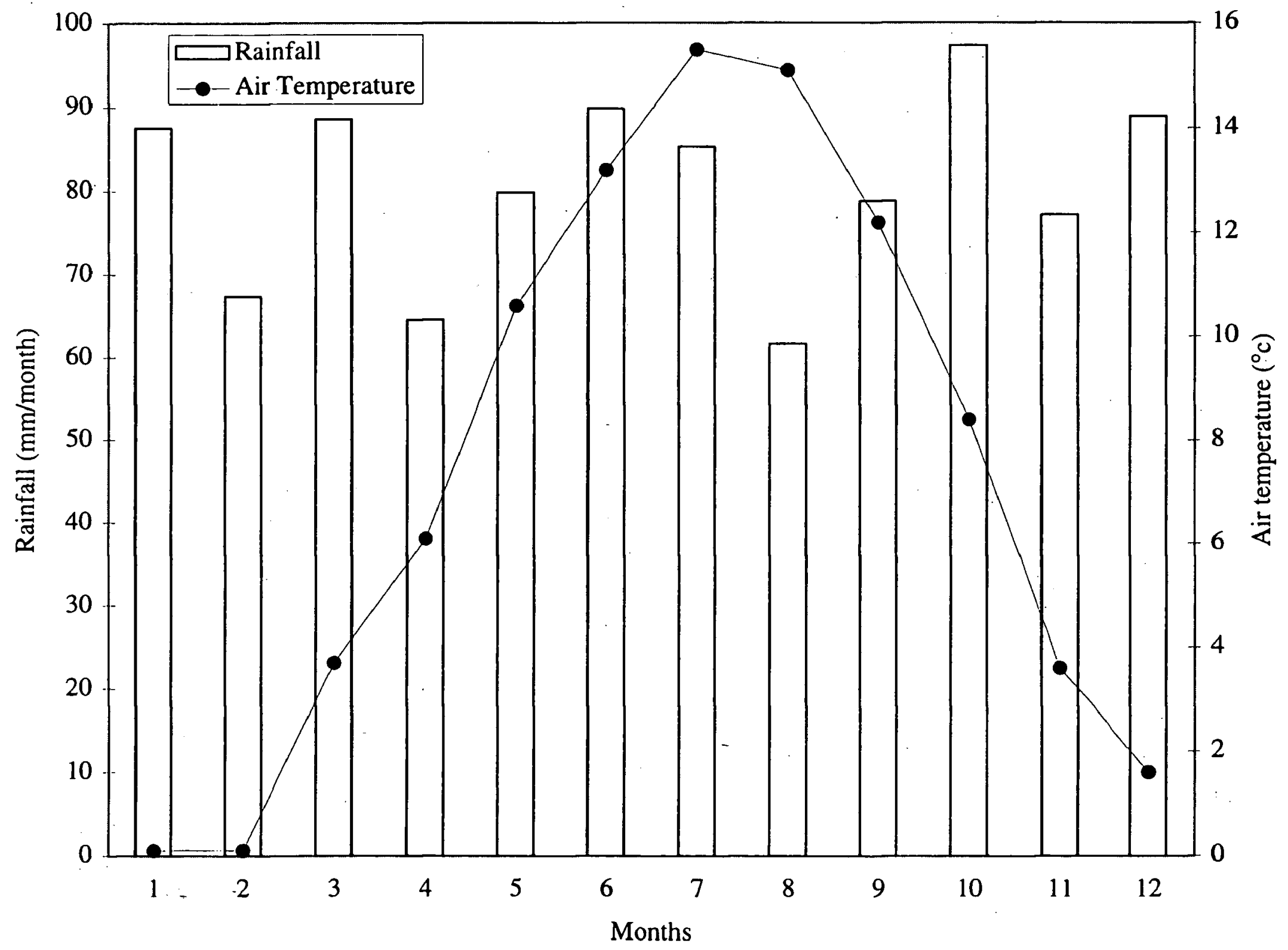

Fig 2. : Evolution of the monthly air temperature mean $\left({ }^{\circ} \mathrm{c}\right)$ and the rainfall mean (mm/mois) between 1980 and 1993 at $\mathrm{Nadrin}$.

Fig 2. : Évolution de la température mensuelle moyenne de l'air $\left({ }^{\circ} \mathrm{c}\right)$ et de la moyenne pluviométrique (mm/mois) entre 1980 et 1993 à Nadrin. 
cal evolution between summer and winter at Nadrin station. All the sites sampled follow this distribution and the annual rainfall value usually occur at 1000 $\mathrm{mm} /$ year.

The material used for this study was mainly obtained by sampling floating debris, trapped behind obstacles. Skimmed collections of debris were taken within a $2 \mathrm{~m}$ stretch of river along the banks with a handnet (mesh size 350 microns). The chironomid exuviae samples were fixed in $95 \%$ alcohol and were sorted in the laboratory. Pupal exuviae were identified to species level with Langton's work (1991). For identification exuviae were mounted in Euparal on permanent slides.

\section{Results and comments}

Four monthly samples collected from the Ourthe basin during 1994 yielded a total of 107 species of Chironomidae. The list of species is given below in table 2 .

Our knowlege of the Belgian Chironomidae shows that 369 species are known to occur. However, some species (Corynoneura Pe2a, Cricotopus (C.) Pe5 and Demicryptochironomus (Irmakia) Pe1) could be the unassociated exuviae of a known adult species already recorded. Following Langton (1991), Cricotopus (C.) $\mathrm{Pe} 5$, a very rare species, has been observed in River Chew (south-west England) and in Rio Ulla (northwest Spain). This rare Cricotopus could be an unnamed species (Langton, pers. com.). The case of Corynoneura Pe2a, a summer-emerging species, is more obvious. Ecological features of the stations (1,2 and 4) where it was collected, agree with those described in Langton (1991). These «mountains-like» sites, situated between 310 and 240 meter altitude (Table 1), keep a high water quality level (I.H.E. 1991). The absence of this intolerant species at Nadrin (station 3) could be explain by the presence of the Nisramont dam which releases rich water and causes water level disturbances. Demicryptochironomus (Irmakia) Pe 1 has been pointed out in a Tunisian river, its finding seems interesting because its distribution is still limited.

The fast flowing system of the streams and the relatively low water temperatures in the river Ourthe during the year lead to the appearance of characteristic montane species, already described in these conditions by Langton, such as : Thienemannimyia pseudocarnea, Microtendipes britteni, Rheotanytarsus distinctissimus, Nanocladius balticus, Eukiefferiella ancyla which larva is phoretic on the Gasteropod Ancylus fluviatilis, a numerous species met at stations 1, 2, 3 and 4 (I.H.E., 1991). The larvae of Epoicladius flavens lives among the gills of Ephemera nymphs, an Ephe- meroptera well represented by Ephemera danica in all the Ourthe stations (I.H.E., 1991).

For most sites, the ecological conditions of the 8 stations fit the known ecology of the new records. Some of these have a noteworthy distribution following the water quality level. The sites (stations 1,2 and 4 )where the number of new records is the highest, are corresponding to a undamaged region. However, one new record has a particular distribution to the other : Psectrocladius sp.A is found in the rich water of Nadrin station (3), closed to the Nisramont dam. Langton (1991) reported it from Lochs in Nothern Scotland. Paraphaenocladius penerasus lives in wet mosses in seepages, by streams and waterfalls, its presence closed to the Nisramont dam is not amazing.

Limnophyes paludis larva feed on drowned grass leaves at the edge of ditches and in temporarily submerged meadow and the recolted exuviae could derived from the dam just upstream of the third station. Nadrin (station 3) is also the only Ourthe station where the lenitic Chironomus (Chaetolabis) macani (Langton 1991) has been recolted, possibly for the same reasons than Limnophyes. In the river Amblève, its presence may be due to the proximity of a fischery where the larva develop in eutrophic conditions.

Some species, belonging to the Orthocladiinae subamily, are exclusively found in the river Amblève at station 5, the highest altitude met ( $405 \mathrm{~m})$ : Eukiefferiella similis, a montane species reported in Central Europe and Tunisia ; Heterotanytarsus apicalis, reported from Northern montanes and lakes; Metriocnemus obscuripes, living in damp places by streams. The high water quality of station 5 and cold water stream could explain the presence of these species. Originally described from the Caucasian mountains (glacial stream, $1700 \mathrm{~m}$ altitude), Diamesa kasymovi found in Tatra mountains (Georgia), the Austrian and Italian Alps, Lebanon and Turkey, is also found at station 5. Following Langton (pers. com.) this species would appear to be kasymovi, but the Diamesa key (Langton 1991) contains three species that are most difficult to separate, moreover Belgium seems an unlikely place to find this species. The best way to record this specimen is kazymovi but it requires confirmation from adult male.

Among the genus Cricotopus, C.(C.) fuscus, indexed as a slow flowing lowland streams and ditches, is effectively found at station 6 (downstream station in the river Amblève) but it is also found in fast flowing water at stations 2 and 4 . On the other hand, $C$. (Nostocladius) lygropis is located in a fast flowing zone at site 4 during the summer as noted by Langton (1991). 
Table 2 : List of «species» showing monthly occurence of exuviae at stations 1 to $8 ;\left({ }^{*}\right)$ denotes new recor ${ }^{-1}$ for Belgium ; (a) denotes recorded in Evrard (1994a) in the river Meuse (deep potamal) ; (b) denotes recorded in Evrard (1994b) in the river Sansom (rhithral).

Tableau 2 : Liste des «espèces» montrant l'évolution mensuelle des exuvies aux stations 1 à 8 ; $\left(^{*}\right)$ indique les nouvelles espèces pour la Belgique ; (a) indique les espèces recensée par Evrard (1994a) dans la Meuse (potamal profond) ; (b) indique les espèces recensée par Evrard (1994b) dans le Samson (rhithral).

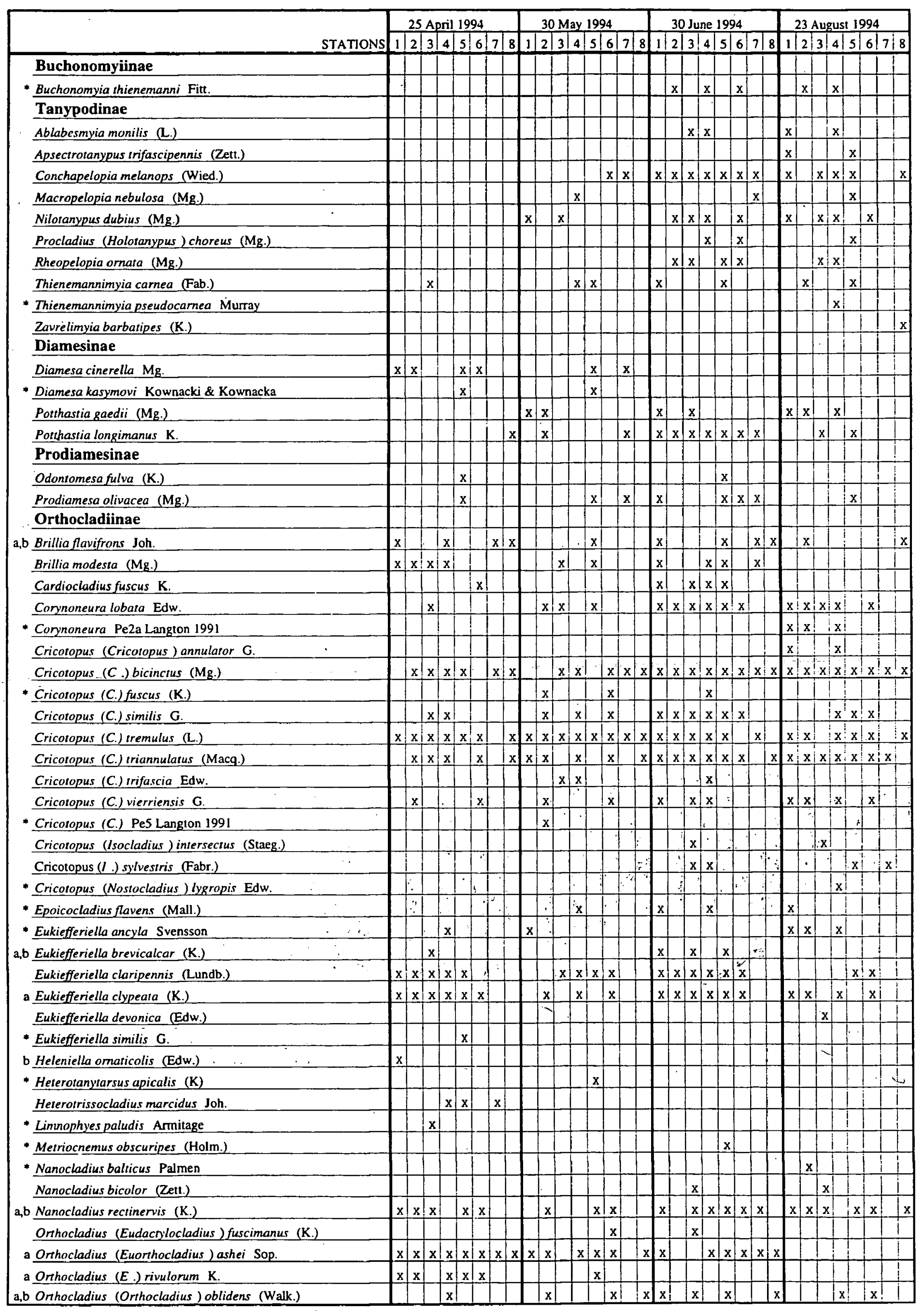




\begin{tabular}{|c|c|c|c|c|c|c|c|c|c|c|c|c|c|c|c|c|c|c|c|c|}
\hline \multirow[b]{2}{*}{ STATIONS } & \multicolumn{5}{|c|}{25 April 1994} & \multicolumn{5}{|c|}{ 30 May 1994} & \multicolumn{5}{|c|}{30 June 1994} & \multicolumn{5}{|c|}{23 August 1994} \\
\hline & \begin{tabular}{|l|l|}
1 & 2 \\
\end{tabular} & & $4 !$ & & \begin{tabular}{|l|l|}
7 & 8 \\
\end{tabular} & $1 / 2$ & $2 \sqrt{3}$ & 4 & & \begin{tabular}{l|l|l}
66 & 7 & 8 \\
\end{tabular} & $8 \sqrt{1 / 2}$ & \begin{tabular}{l|l|l}
2 & 3 & 4 \\
\end{tabular} & $4 \mid 5$ & 617 & $7 ! 8$ & \begin{tabular}{|l|l|}
1 & 2 \\
\end{tabular} & $3|4|$ & & $6: 7$ & \\
\hline a Orhocladius $(O$ ) obumbratus Joh. & $x \mid x$ & $x$ & $\mathrm{x}$ & $x$ & & $x: x$ & $x$ & & \begin{tabular}{|l|l|l|}
$x$ & $x$ \\
\end{tabular} & $\mathrm{x}$ & $x$ & $x \mid x$ & $x$ & $\mathbf{x}$ & & & i & & & \\
\hline Orhocladius (O.) rubicundus (Mg.) & $x$ & $x$ & $x$ & $x$ & $x$ & $x \mid x$ & $x \mid x$ & $x$ & \begin{tabular}{|l|l|l|}
$x$ & $x$ \\
\end{tabular} & $\mathrm{x}$ & $x|x| 2$ & \begin{tabular}{l|l}
$x$ & $x$ \\
\end{tabular} & $x \mid x$ & $x$ & $x \mid x$ & $|x| x \mid$ & $x$ & 8 & $x$ & $x$ \\
\hline Paracricotopus niger (K.) & & & 1 & $\underline{x}$ & & & & & \begin{tabular}{|l|l}
$x$ & $x$ \\
\end{tabular} & $x$ & & $x|x|$ & $x$ & $x$ & & $x$ & $|x|$ & $|x|$ & $x$ & \\
\hline a,b Parakiefferiella bathophila (K.) & $x$ & & & & & & & & $x$ & & & & & & & 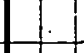 & & & & \\
\hline a,b Parametriocnemus stylatus (K.) & $x$ & $x$ & $x$ & & & & & & & & $\mathrm{x}:$ & $x|x| x$ & $\mathrm{x}$ & & & $x$ & & & & \\
\hline - Paraphaenocladius penerasus (Edw.) & & $x$ & $\mathrm{x}$ & & & & & & & & & & & & & & & & & \\
\hline Paratrichocladius rufiventris (Mg.) & $x$ & $\mathrm{x}$ & $x$ & $x$ & & $x$ & $x \mid x$ & $x$ & $x \mid x$ & \begin{tabular}{l|l}
$x$ & $x$ \\
\end{tabular} & $x|x| 2$ & \begin{tabular}{l|l}
$x$ & $x$ \\
$x$
\end{tabular} & $x \mid x$ & & $x \mid x$ & $x|x|$ & $x \mid x$ & $\frac{x}{x}$ & $x$ & $x$ \\
\hline Paratrissocladius excerptus (Walk.) & & & & & & & $x$ & & & & & & & & $x$ & $|x|$ & $|x|$ & & $\mathrm{x}$ & $x$ \\
\hline Psectrocladius (Psectrocladiu s) psilopterus K. & & & & & & & & & & & & & & & $\mathrm{x}$ & & 7 & & & \\
\hline * Psectrocladius (P.) sp. A Langton 1980 & & & & & & & & & & & & $x$ & & & & & $x$ & & & \\
\hline Rheocricotopus (Psilocricotopus) chalybeatus (Edw.) & & & & & & & & & & & & & & & & & $x \mid x$ & & $\mathrm{x}$ & \\
\hline Rheocricotopus (Rheocricotopus) fuscipes (K.) & $x$ & $\mathrm{x}$ & & $\begin{array}{lll}x & x \\
\end{array}$ & $x \mid x$ & $x$ & $\mathrm{x}$ & & \begin{tabular}{|l|l}
$x$ & $x$ \\
\end{tabular} & $x \times x$ & $\mathrm{x}$ & & $\underline{x}$ & & $x \mid x$ & & & & & $t^{\prime}$ \\
\hline a,b Rheorthocladius sp. A Thienemann & & & & & & & & & & & 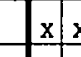 & $x$ & $\mathrm{x}$ & $\mathrm{x}$ & & $x$ & & 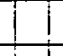 & & \\
\hline a,b Synorhocladius semivirens (K.) & \begin{tabular}{|l|l|}
$x$ & $x$ \\
\end{tabular} & $x$ & $\mathrm{x}$ & $x \mid x$ & & $x \mid x$ & $x \times$ & $x$ & \begin{tabular}{|l|l|l|}
$x$ & $x$ \\
\end{tabular} & $x$ & $x$ & \begin{tabular}{|l|l}
$x$ & $x$ \\
\end{tabular} & $x$ & $x$ & & $\mathrm{x} \mid \mathrm{x}$ & $x$ & $x$ & $x$ & \\
\hline Thienemanniella clavicomis (K.) & $x$ & & & & & & $x$ & & & & D & & & & & $x$ & & $x$ & & \\
\hline Tvetenia calvescens (Edw.) & \begin{tabular}{|l|l|}
$x$ & $x$ \\
\end{tabular} & $x$ & $x$ & $\underline{x}$ & & $x x$ & $x \mid x$ & $x$ & \begin{tabular}{|l|l}
$x$ & $x$ \\
\end{tabular} & $x$ & \begin{tabular}{l|l}
8 \\
$x$
\end{tabular} & \begin{tabular}{|l|l|l}
$x$ & $x$ & $x$ \\
\end{tabular} & $x x$ & $x$ & & $x: x$ & $x$ & $x$ & $x$ & \\
\hline Tvetenia verralli (Edw.) & \begin{tabular}{|l|l|}
$x$ & $x$ \\
\end{tabular} & $x$ & $x$ & $\begin{array}{ll}x \\
x\end{array}$ & & & $x \times$ & $x$ & & $x$ & $x$ & $x|x| x$ & $x$ & $x$ & & $x$ & & & $x$ & \\
\hline Chironominae - Chironomini & & & & & & & & & & & & & & & & & & & & \\
\hline Chironomus (Chaetolabis) macani Freeman & & & & & & & & & $\mathrm{x}$ & & & $\mathrm{x}$ & $\mathrm{x}$ & & & & $x$ & $x$ & & \\
\hline Chironomus (Chironomus) riparius $\mathrm{Mg}$. & & & & & $x=$ & & & & & $x \mid x$ & & & & & $x$ & & & $\mathrm{x}$ & & $x$ \\
\hline Cryptochironomus denticulatus $\mathbf{G}$. & & & & & & & & & & & $x: 2$ & $x$ & $x$ & & & $x$ & $\mid x$ & & & \\
\hline Demicryptochironomus (Demicryptochironomus) vulneratus (2) & Zett.) & & & & & & & & & & $\mathrm{x}: \mathrm{s}$ & $\mathrm{x}$ & & & & & & & & \\
\hline - Demicryptochironomus (Irmakia) Pe I Langton 1991 & & & & & & & & & & & & 8 & $x$ & & & & & & & \\
\hline Dicrotendipes nervosus (Staeg.) & & & & & & & & & & & & $\mathrm{x}$ & & & & & $|x|$ & & & \\
\hline Dicrotendipes notatus (Mg.) & & & & & & & & & & & & 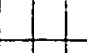 & & & & & $x$ & & & \\
\hline Glyptotendipes (Phytotendipes) pallens (Mg.) & & & & & & & & & & & & $x$ & & & & & $x$ & & & \\
\hline Glyptotendipes (Phytotendipes) paripes Edw. & & & & & & & & & & & & & & & & & $x$ & & & \\
\hline${ }^{*}$ Microtendipes britteni (Edw.) & & & & & & & $\mathrm{x}$ & & & & & & & & & & & 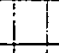 & & \\
\hline Microtendipes chloris (Mg.) & $x$ & $x$ & & & & & & & & & & $x: x$ & $x$ & & & $\mathrm{x} x$ & $x$ & $x$ & & \\
\hline Microtendipes diffinis (Mg.) & & & & & & & & & & & & $x$ & & & & $\mathrm{x} \times \mathrm{x}$ & $x$ & & & \\
\hline Microrendipes rydalensis (Edw.) & & & & & & & & & & & & 4 & & & & $x$ & $|x| x \mid$ & $\underline{1}$ & & \\
\hline$\therefore$ Parachironomus arcuatus (G.) & & & & & & & & & & & & $x$ & & & & 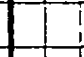 & 11 & 1 & & \\
\hline Parachironomus frequens (Joh.) & & & & & & & & & & & & & & & & & $x$ & & & \\
\hline Paracladopelma camptolabis (K.) & $x$ & & & & & & & & & & & $x$ & & & & & & & & \\
\hline Parasendipes albimanus (Mg.) & & & & & & $\mathrm{x}$ & & & & & & $x$ & & & & & 1 & $|x|$ & 7 & \\
\hline Phaenopsectra flavipes (Mg.) & & & & & $x$ & & & & & & & $x$ & & & & L & $\mathrm{x}$ & $x$ & & \\
\hline Polypedilum (Polypedilum ) albicorne (Mg.) & & & & & $x$ & $x$ & & &. & & 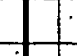 & $\because$ & & & & 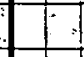 & .1. & $|x|$ & & \\
\hline Polypedilum (P.) convictum (Walk.) & & & & & & & & $x$ & \begin{tabular}{|l|l}
$x$ & $x$ \\
\end{tabular} & $\underline{x}$ & $x:$ & \begin{tabular}{l|l|l}
$x$ & $x$ & $x$ \\
\end{tabular} & $x \mid x$ & & & $x$ & $x$ & $|x|$ & & \\
\hline Polypedilum (P.) cultellatum G. & & & & & & & & & & & & & $x$ & & & $\mathrm{x}:$ & & $x !$ & & \\
\hline Polypedilum (P.) laetum (Mg.) & & & & & & & & & & & $x$ & & & & & . & $x$ & & & \\
\hline Polypedilum (Tripodura) pullum (Zett.) & & & & & & & & & & & & & & & & & $x$ & 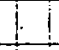 & 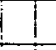 & \\
\hline Chironominae - Tanytarsini & & & & & & & & & & & & & & & & $F$ & . & & & \\
\hline Cladotanytarsus.mancus (Walk.) & & & & & & & & & & & & & & & & $x$ & $x$ & 8 & & \\
\hline Cladotanytarsus vanderwulpi (Edw.) & & & & & & $x$ & & $x$ & $x$ & & & & & & & & & & & \\
\hline Micropsectra atrofasciata (K.) & \begin{tabular}{|l|l|}
$x$ & $x$ \\
\end{tabular} & $x$ & & $\mathrm{x}$ & & & \begin{tabular}{|l|l}
$x$ & $x$ \\
\end{tabular} & $x$ & & & $\mathrm{x}: 2$ & \begin{tabular}{|l|l|l} 
& $x$ \\
\end{tabular} & $x$ & & \begin{tabular}{|l|l}
$x$ \\
$x$
\end{tabular} & $x$ & & $x$ & $z$ & \\
\hline Micropsectra notescens (Walk.) & \begin{tabular}{|l|l|}
$x$ & $x$ \\
\end{tabular} & $x$ & $x:$ & 4 & & & & & 4 & & $x$ & $|x|$ & & & & 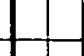 & \begin{tabular}{|c|c} 
\\
\end{tabular} & & & \\
\hline a Paratanytarsus dissimilis Joh. & & & & $x$ & & & & & $x$ & & 12 & \begin{tabular}{|l|l}
$x$ & $x$ \\
\end{tabular} & $x: x$ & & & 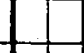 & $x$ & $x$ & $x$ & \\
\hline * Rheolanytarsus distinctissimus $\mathrm{Br}$. & & & & & & & & & & & $x$ & $\mathrm{x}$ & & & & $x$ & $x \mid x$ & 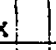 & & \\
\hline a,b Rheotanytarsus pentapoda $\mathrm{K}$. & $x$ & $x$ & & & & $x:$ & $x$ & $\mathrm{x}$ & $x$ & & $\mathrm{x}$ & $x$ & & & & $x: x$ & $x \mid x$ & $x$ & & \\
\hline Rheotanytarsus rhenanus Klink. & & & & & & & & & & & & & & & & $\mathrm{x}$ & 11 & & $\mathbf{x}$ & \\
\hline a,b Tanyzarsus brundini Lind. & $x$ & $x$ & $x$ & & & & $x$ & & & & & \begin{tabular}{|l|l|l}
$x$ & $x$ & 2 \\
\end{tabular} & $x \mid x$ & & & \begin{tabular}{|l|l|}
$x$ & $x$ \\
\end{tabular} & $x: x$ & & $x$ & \\
\hline Tanyzarsus ejuncidus (Walk.) & & & & & & & & & & & & 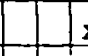 & $x$ & & & + & 1 & $x$ & & \\
\hline Tanyzarsus eminulus (Walk.) & & & & & & & & & $x$ & & & \begin{tabular}{|l|l|}
$x$ & $x$ \\
\end{tabular} & $x$ & $|x|$ & & $x \mid x$ & $x \times x$ & \begin{tabular}{|l|l|}
$x$ \\
\end{tabular} & $x$ & \\
\hline Tanyzarsus heusdensis G. & & & & & & & & & & & & & & & & $x$ & $x$ & $x: x$ & $x$ & \\
\hline Tanytarsus pallidicomis (Walk.) & & & & & & & & & & & & & & & & & $x$ & $x \mid$ & & \\
\hline Virgata & & & & & & & & $x$ & & $x$ & & $|x|$ & $x$ & & & $x: x$ & $8 \times x$ & & & \\
\hline
\end{tabular}


Of the one hundred and seven species recorded during this survey, 17 are new to the fauna of Belgium with a possible additional three taxa (see Goddeeris \& Behen (1991); Evrard (1994a,b), for details). Most of the new records belong to the Orthocladiinae, with 13 taxa. The subfamily Buchonomyinae Buchonomyia thienemanni Fittkau, is found for the first time in Belgium. This unique species is being prepared for a detailed taxonomic description. The survey of several Walloon rivers during 1995 is likely to further increase the number of species on the Belgian Chironomid list.

\section{Acknowledgments}

I am thankful to Dr Peter Langton for taxonomic assistance and to Prof. J.C. Micha for providing facilities. Also many thanks to an anonymous referee for his valuable comments.

\section{References}

Evrard M., 1994a. - Check-list of the Chironomidae (Diptera) of the river Meuse and two of its tributaries. Annls Limnol. $30: 123$ 129.

Evrard M., 1994b. - Evolution journalière de la dérive des exuvies nymphales de Chironomidae (Diptera) dans une rivière salmonicole (le Samson, Belgique). Belg. J. Zool. 124 :115-126.
Goddeeris B. \& Behen F., 1991. - Chironomidae. In «Catalogue of the Diptera of Belgium» by Grootaert P., De Bruyn L. \& De Meyer M. Documents de travail 70 de l'Institut Royal des Sciences Naturelles de Belgique, Bruxelles : 46-56.

Herman D., Duschesne S. \& Parotte M.F., 1985. - Les pollutions et leurs incidences écologiques. Etude de l'Ourthe, l'Amblève, la Vesdre, la Gueule et affluents. Union des pêcheurs de l'Ourthe et de l'Amblève : $264 \mathrm{p}$.

Institut d'Hygiène et d'Epidémiologie (I.H.E.), 1991. - Rapport. Réseau hydrobiologique. Programme : 4204, 1991 : Qualité des eaux de surface. Section eau : $43 \mathrm{p}$.

Ketttani K., Vilchez-Quero A., Calle Martinez D. \& El Ouazzani T., 1994. - Les Chironomidés (Diptera) du bassin de l'Oued Laou (Versant méditerranéeen du Rif, Maroc). Annls Limnol. 30 : 2532.

Langton P.H., 1991. - A key to pupal exuviae of West Palaearctic Chironomidae. P.H. Langton ed. Huntington, Cambridgeshire, England : $386 \mathrm{p}$.

Micha J.-C., 1969. - Etude quantitative du benthos d'une rivière de Belgique : l'Ourthe Liégeoise. Annls Limnol. 6 (3) : 62-75.

Ruse L.P \& Wilson R.S., 1995. - Long-term assessment of water and sediment quality of the river Thames using chironomid pupal skins. In «Chironomids from genes to ecosystems». CRANSTON P., Ed, Canberra, Australia : 113-123. 